\title{
Pengaruh Intervensi Mind-Body Terhadap Peningkatan Kualitas Hidup Lansia (Studi Literatur) \\ ${ }^{1}$ Nur Amelza Wahyu Aqila, ${ }^{2}$ Alisa Qtrunnada, ${ }^{3}$ Alaia Pramesti Pasa, ${ }^{4}$ Assyifa Fitri Anggraeni, dan ${ }^{5}$ Olivia Filziah Ningrum
}

Program Studi D IV Fisioterapi, Jurusan Fisioterapi, Poltekkes Kemenkes Jakarta III Jl. Melati 2 No.15, RT.001/RW.009, Jatiwarna, Kec. Pd. Melati, Kota Bks, Jawa Barat17415 Email: nuramelza@gmail.com

\begin{abstract}
ABSTRAK
Latar Belakang: Prevalensi lansia pada tahun 2020 mencapai 9,92\% dari seluruh penduduk di Indonesia yang mana lansia pasti melewati proses menuaan sehingga terjadi penurunan kemampuan fungsional yang memengaruhi kualitas hidupnya. Intervensi Mind Body adalah intervensi yang didasarkan pada beberapa praktik yang dirancang untuk memfasilitasi dampak positif pikiran pada tubuh yang diharapkan dapat meningkatkan kualitas hidup Lansia.Tujuan: Penelitian ini bertujuan untuk mengetahui pengaruh Intervensi Mind Body terhadap kualitas hidup pada lansia. Metode: Desain penelitian ini yaitu studi literatur, variabel bebas Intervensi Mind Body dan variabel terikatnya kualitas hidup pada lansia. Pencarian literatur dilakukan di 3 search engine yaitu PubMed, Science Direct, dan Sementic Scholar. Hasil: Jumlah literatur yang memenuhi kriteria sebanyak 5 literatur. Intervensi Mind Body yang diberikan antara lain Tai Chi, Yoga, dan Pilates. Pengukuran kualitas hidup yang digunakan pada 5 literatur antara lain, yaitu SF-36, EQ-5D-5L, LEIPAD Questionnaire, dan Cronbach's Apha Satisfaction Life Scale. Hasil intervensi menunjukkan adanya peningkatan kualitas hidup pada lansia. Kesimpulan: Intervensi Mind Body efektif untuk meningkatkan kualitas hidup dengan meningkakan komponenkomponen kualitas hidupnya seperti kesehatan fisik serta mental.
\end{abstract}

Kata kunci: Lansia, Intervensi Mind Body, Kualitas Hidup

\section{ABSTRACT}

Background: The prevalence of the elderly in 2020 reaches $9.92 \%$ of the entire population in Indonesia, where the elderly must go through the aging process so that there is a decline in functional abilities that affect their quality of life. Mind Body Interventions are interventions based on several practices designed to facilitate the positive impact of the mind on the body which is expected to improve the quality of life of the Elderly. Objective: This study aims to determine the effect of Mind Body Intervention on quality of life in the elderly. Methods: The design of this study is study literature, independent variables namely Mind Body Intervention and the dependent variable namely Quality of Life in the Elderly. Literature finding conducted on 3 search engine namely PubMed, Science Direct, and Sementic Scholar. Results: The amount of literature that has met the criteria is 5 literatures. The Mind Body Intervention provided include Tai Chi, Yoga, and Pilates. The Quality of Life measurements used in 5 literatures include the SF-36, EQ-5D-5L, LEIPAD Questionnaire, dan Cronbach's Apha Satisfaction Life Scale. The results of the intervention showed an increase Quality of Life in Elderly. Conclusion: Mind Body Intervention is effective in improving the quality of life by improving the components of the quality of life such as physical and mental health.

Keywords: Elderly, Mind Body Intervention, and Quality of Life. 
N.A.W Aqila; A Qtrunnada; A.P Pasa; A.F Anggraeni, dan O.F Ningrum

Fisiomu.2021 Vol 2(3): 162-175

DOI: $10.23917 /$ fisiomu.v2i3.15201

\section{Pendahuluan}

Menurut Peraturan Menteri Kesehatan No. 65 tahun 2013 lansia adalah seseorang yang telah mencapai usia 60 (enam puluh) tahun ke atas. Secara global populasi lansia dunia saat ini berada pada era ageing population yaitu jumlah presentasi penduduk yang berusia 60 tahun keatas telah melebihi angka $7 \%$ dari total penduduk (Kemenkes RI, 2017). Presentasi lansia Indonesia pada 2020 yaitu 9,92\% (26 juta dari seluruh penduduk Indonesia) dengan $64,29 \%$ diantaranya yaitu lansia muda berumur 60-69 tahun diikuti dengan 27,23\% meruppakan lansia madya dengan umur 70-29 tahun dan 8,49\% lansia tua berumur lebih dari 80 tahun (Badan Pusat Statistik, 2020).

Meningkatnya usia pada lansia, maka proses penuaan juga semakin berlanjut. Proses penuaan yaitu suatu proses menghilangnya secara progresif kemampuan jaringan untuk memperbaiki diri atau mengganti diri dan memertahankan struktur dan fungsi normalnya (Halawa, 2014). Proses menua pada lansia mencakup kemunduran fungsi biologis, fisiologi, psikologi, dan sosisologi (Halawa, 2014). Di masa tuanya, Lansia harus tetap produktif demi keberlanjutan hidupnya atau keluarganya. Data Susenas 2020 menunjukkan bahwa rumah tangga lansia di Indonesia sebesar $28,48 \%$ dengan $62,28 \%$ diantaranya dikepalai oleh lansia dan 9,80\% lansia tinggal sendiri (Statistik, 2020).Maka peningkatan kualitas hidup pada lansia sangat krusial untuk keberlanjutan hidup lansia.

Kualitas Hidup adalah persepsi individual terhadap posisinya dalam kehidupan, dalam konteks budaya, sistem nilai dimana mereka berada dan hubungannya terhadap tujuan hidup, harapan, standar, dan lainnya yang terkait. Masalah yang mencakup kualitas hidup sangat luas dan kompleks termasuk masalah kesehatan fisik, status psikologik, tingkat kebebasan, hubungan sosial dan lingkungan dimana mereka berada (World Health Organization, 2012). Kualitas hidup dapat diukur dengan kuisioner yang sudah distandardisasi seperti World Health Organization Quality of Life (WHOQOL-BREF), International Physical Activity Questionnaire Short Version (IPAQ-SF), Short From Survey 36 (SF-36), LEIPAD dan instrumen lainnya (Schoene et al., 2019)

Peran penting fisioterapi untuk mengatasi permasalahan khususnya penurunan fungsional akibat proses penuaan yang memengaruhi kualitas hidup pada lansia sesuai dengan peran fisioterapi menurut PMK Nomor 80 tahun 2013 tentang penyelenggaraan pekerjaan dan praktik fisioterapi. Dalam peraturan tersebut Fisioterapi adalah bentuk pelayanan kesehatan yang ditujukan kepada individu dan/atau kelompok untuk mengembangkan, memelihara dan memulihkan 
N.A.W Aqila; A Qtrunnada; A.P Pasa; A.F Anggraeni, dan O.F Ningrum

Fisiomu.2021 Vol 2(3): 162-175

DOI: $10.23917 /$ fisiomu.v2i3.15201

gerak dan fungsi tubuh sepanjang rentang kehidupan dengan menggunakan penanganan secara manual, peningkatan gerak, peralatan (fisik, elektroterapeutis dan mekanis) pelatihan fungsi, komunikasi (Kemenkes RI , 2015).

Salah satu bentuk upaya yang dapat diaplikasikan yaitu dengan intervensi mind-body. Intervensi Mind-Body adalah latihan yang menekankan pada peregangan dan relaksasi otot, peltihan koordinasi fisik dan kontro napas serta gerak. Intervensi Mind Body yang melibatkan gerakan meditasi dapat berfungsi sebagai peluang yang meningkatkan domain kesehatan psikologis seperti kualitas hidup, gejala depresi, Fear of Falling (FoF), dan kualitas tidur pada lansia (Yu et al., 2021).

Bentuk-bentuk latihan Intervensi Mind Body menggunakan gerakan dalam hubungannya dengan meditatif. Komponen dasar yang mencangkup pernapasan aktif dan pasif yang ditandai dengan berbagai tindakan seperti peregangan dan relaksasi otot rangka, tubuh terkoordinasi, tinggi tingkat konsentrasi, gerakan pernapasan teratur dan teknik pernapasan. Dengan cara ini, bukti dari intervensi tersebut tidak hanya mempengaruhi dua tingkat yakni fungsi kognitif dan fisik tetapi juga berbagai domain fungsi psikologis di antara lansia ( $\mathrm{Yu}$ et al., 2021).

Mengacu dari penjabaran di atas, maka penelitian ini penting untuk mengidentifikasi pengaruh intervensi mind-body terhadap kualitas hidup pada lansia melalui studi literatur.

\section{Metode Penelitian}

Penelitian ini menggunakan jenis penelitian deskriptif dengan desain studi literatur yang memanfaatkan berbagai literatur hasil penelitian sebagai sumber data. Metode pengumpulan data dilakukan dengan mengunduh literatur yang sesuai dengan kriteria inklusi dan ekslusi pada 3 search engine yaitu, PubMed, Science Direct, dan Sementic Scholar. Populasi yang diambil pada penelitian ini adalah semua literatur yang relevan dengan penelitian yaitu mind body intervention dengan outcome kualitas hidup pada lansia.

Peneliti melakukan pencarian literatur pada 3 search engine yang berbeda menggunakan kata kunci yang ditetapkan berdasarkan pendekatan PICOS yaitu " Elderly AND Mind Body Intervention OR Mindy Body Exercise AND Quality Of Life AND Randomized Controlled Trial OR Clinical Trial “.

Hasil pencarian literatur yang didapat berdasarkan kata kunci kemudian diseleksi berdasarkan kriteria inklusi dan eksklusi. Kriteria inklusi penelitian ini meliputi subjek penelitian yaitu lansia; intervensi yang diberikan Intervensi Mind Body dengan outcome kualitas hidup; desain penelitian Clinical Trial atau Randomized Controlled Trial (RCT); memiliki akses terbuka penuh dan tahun publikasi antara 
N.A.W Aqila; A Qtrunnada; A.P Pasa; A.F Anggraeni, dan O.F Ningrum

Fisiomu.2021 Vol 2(3): 162-175

2016 - 2021. Kriteria eksklusi penelitian ini adalah literatur yang tidak berbahasa Inggris.

Literatur yang didapatkan berdasarkan kriteria inklusi dan eksklusi kemudian dilakukan pengecekan duplikasi dengan menggunakan aplikasi Mendeley. Selanjutnya dilakukan pengolahan data dengan cara ekstraksi data yang meliputi tahun terbit, desain penelitian, subjek/sampel, perlakuan pada kelompok intervensi dan kelompok pembanding, outcome dan alat ukurnya.

\section{Hasil}

Pencarian dilakukan pada 3 search engine yaitu, PubMed, Science Direct, dan Sementic Scholar. Adapun proses pencarian dapat dilihat pada gambar 1 berikut ini.

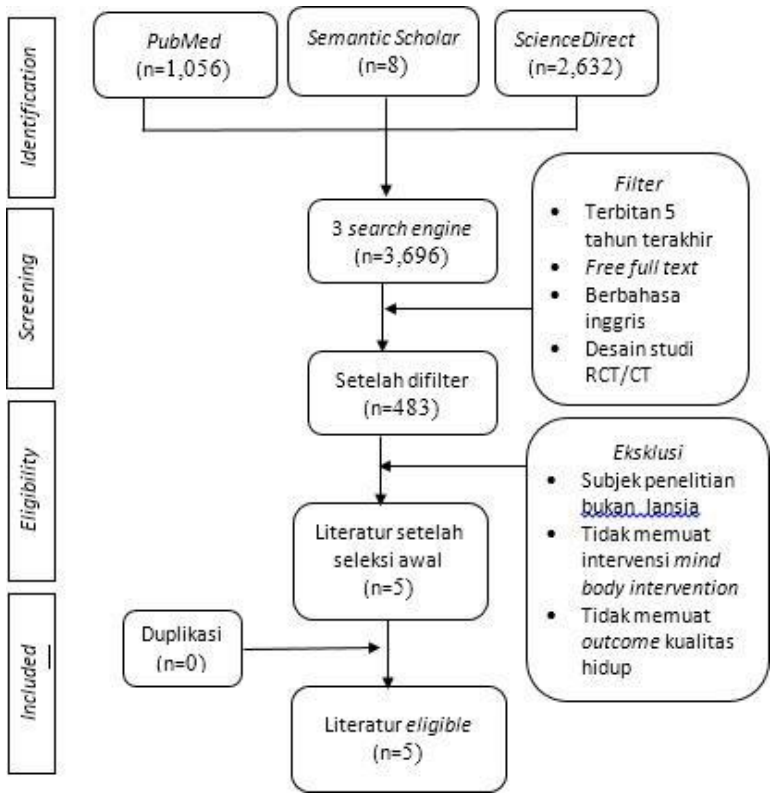

Gambar 11 Diagram Seleksi Literatur
DOI: $10.23917 /$ fisiomu.v2i3.15201

Pada hasil awal pencarian literatur dengan kata kunci di 3 search engine yaitu, PubMed, Science Direct, dan Sementic Scholar. yang berbeda didapatkan literatur sejumlah 3,696 dengan rincian 1,056 literatur di PubMed, 8 literatur di Semantic Scholar, dan 2,632 literatur di Science direct. Setelah dilakukan penyaringan, 3,213 literatur dikeluarkan karena tidak sesuai tahun publikasi maksimal 5 tahun terakhir , tidak free full text dan bukan penelitian dengan desain studi Randomized controlled trial $(R C T)$ ataupun Clinical trial (CT) sehingga tersisa 483 literatur. Kemudian literatur diseleksimanual sesuai dengan inklusi. Hasil akhir seleksi didapatkan 5 literatur, kemudian diunduh dan dilakukan pemeriksaan duplikasi menggunakan aplikasi manajemen referensi Mendeley, namun tidak terdapat duplikasi.

Literatur yang telah dilakukan pengecekkan duplikasi selanjutnya diekstraksi datanya menggunakan instrumen ekstraksi data. Hasil ekstraksi data selanjutnya dikoding. Hasil dari pengolahan data terdapat pada tabel 1 dibawah ini.

Tabel 1.1 Hasil Distribusi Data

\begin{tabular}{lccc}
\hline No & Uraian & Jumlah & Persentase \\
\hline $\mathbf{1}$ & \multicolumn{2}{c}{ Perlakuan } \\
\hline \multicolumn{3}{l}{ Kelompok Intervensi Intervensi } & Mind Body \\
\hline & Tai Chi & 2 & $40 \%$ \\
& Yoga & 2 & $40 \%$ \\
& Pilates & $20 \%$ \\
\hline Kelompok control & 1 & $100 \%$ \\
\hline \multicolumn{2}{l}{ Tanpa Perlakuan } \\
\hline
\end{tabular}


N.A.W Aqila; A Qtrunnada; A.P Pasa; A.F Anggraeni, dan O.F Ningrum

Fisiomu.2021 Vol 2(3): 162-175

DOI: $10.23917 /$ fisiomu.v2i3.15201

\begin{tabular}{|c|c|c|c|}
\hline 2 & \multicolumn{3}{|c|}{ Dosis Intervensi } \\
\hline & \multicolumn{3}{|l|}{ Durasi Latihan } \\
\hline & 60 menit/sesi & 5 & $100 \%$ \\
\hline & \multicolumn{3}{|l|}{ Frekuensi intervensi } \\
\hline & $1 \mathrm{sesi} / \mathrm{minggu}$ & 1 & $20 \%$ \\
\hline & 2 sesi / minggu & 1 & $20 \%$ \\
\hline & 3 sesi / minggu & 1 & $40 \%$ \\
\hline & 5 sesi / minggu & 1 & $20 \%$ \\
\hline & $\begin{array}{l}\text { Tidak menyantumkan } \\
\text { penjelasan sesi }\end{array}$ & 1 & $20 \%$ \\
\hline & \multicolumn{3}{|l|}{ Lama Intervensi } \\
\hline & 6 minggu & 1 & $20 \%$ \\
\hline & 8 minggu & 1 & $20 \%$ \\
\hline & 10 minggu & 1 & $20 \%$ \\
\hline & 12 minggu & 2 & $40 \%$ \\
\hline 3 & \multicolumn{3}{|c|}{ Outcome \& Alat Ukur } \\
\hline & $\begin{array}{l}\text { Kualitas Hidup: } \\
\text { a. SF-36 } \\
\text { b. EQ-5D-5L } \\
\text { c. LEIPAD Quest } \\
\text { d. Cronbach's Apha } \\
\text { Satisfaction Life Scale }\end{array}$ & $\begin{array}{l}2 \\
1 \\
1 \\
1\end{array}$ & $\begin{array}{l}40 \% \\
20 \% \\
20 \% \\
20 \%\end{array}$ \\
\hline
\end{tabular}

a. Intervensi, Kontrol, dan Durasi

Jenis Intervensi Mind Body yang dilakukan pada penelitian berupa Tai Chi sebanyak 40\% (Tajik et al., 2018; Oh and Kang, 2019), Yoga sebanyak 40\% (Tew et al., 2017; Groessl et al., 2018), Pilates sebanyak 20\% (Gabizon et al., 2016) dengan masing-masing penelitian memiliki 100\% kelompok kontrol. Sebanyak $100 \%$ penelitian melakukan intervensinya selama 60 menit.

b. Frekuensi Latihan

Rincian frekuensi latihan yaitu $20 \%$ frekuensi latihan 1 sesi per minggu (Tew et al., 2017) , 20\% 2 sesi per minggu (Groessl et al., 2018), 20\% 3 sesi per minggu (Gabizon et al., 2016), 20\% 5 sesi per minggu (Oh and Kang, 2019), dan $20 \%$ tidak menyantumkan penjelasan sesi (Tajik et al., 2018).

c. Lama Intervensi

Semua literatur menyntumkan lama latihan, adapun rinciannya yaitu $20 \%$ melakukan intervensi selama 6 minggu (Oh and Kang, 2019), 20\% selama 8 minggu (Tajik et al., 2018), $20 \%$ selama 10 minggu (Groessl et al., 2018), dan $40 \%$ selama 12 minggu (Gabizon et al., 2016; Tew et al., 2017)

d. Outcome dan Alat Ukur

Outcome yang terdapat dalam literatur $100 \%$ membahas peningkatan kualitas hidup lansia dengan alat ukur yang berbeda-beda. Adapun rincian alat ukur yang digunakan yaitu 40\% menggunakan SF-36 (Gabizon et al., 2016; (Groessl et al., 2018), 20\% menggunakan EQ5D- 5L (Tew et al., 2017), 20\% menggunakan LEIPAD Questionnaire (Tajik et al., 2018), dan 20\% menggunakan Cronbach 's Apha Satisfaction Life Scale (Oh and Kang, 2019) sebagai alat ukur. 
N.A.W Aqila; A Qtrunnada; A.P Pasa; A.F Anggraeni, dan O.F Ningrum

Fisiomu.2021 Vol 2(3): 162-175

Tabel 21 Ekstraksi Data

DOI: $10.23917 /$ fisiomu.v2i3.15201

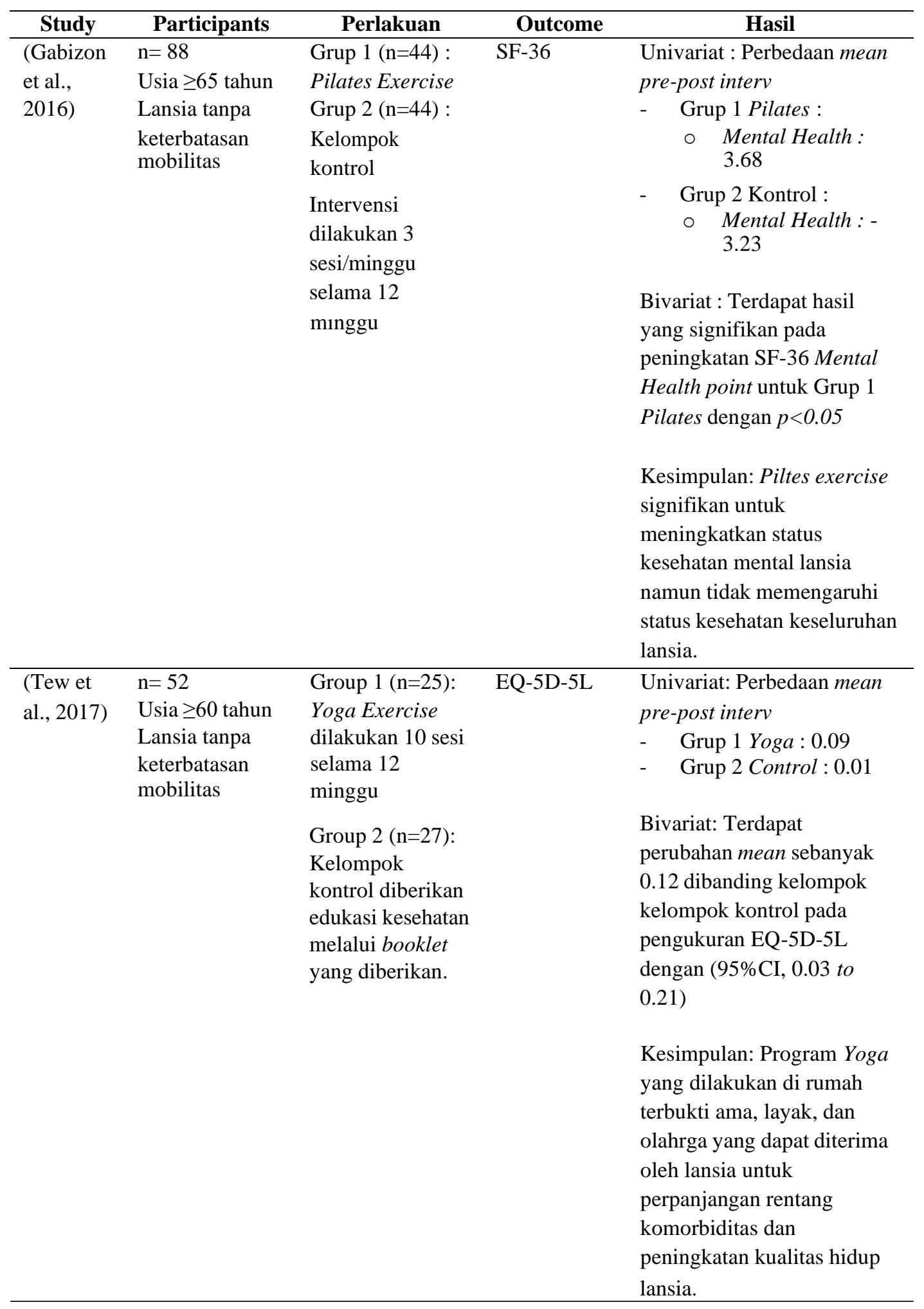


${ }^{1}$ N.A.W Aqila; A Qtrunnada; A.P Pasa; A.F Anggraeni, dan O.F Ningrum Fisiomu.2021 Vol 2(3): 162-175

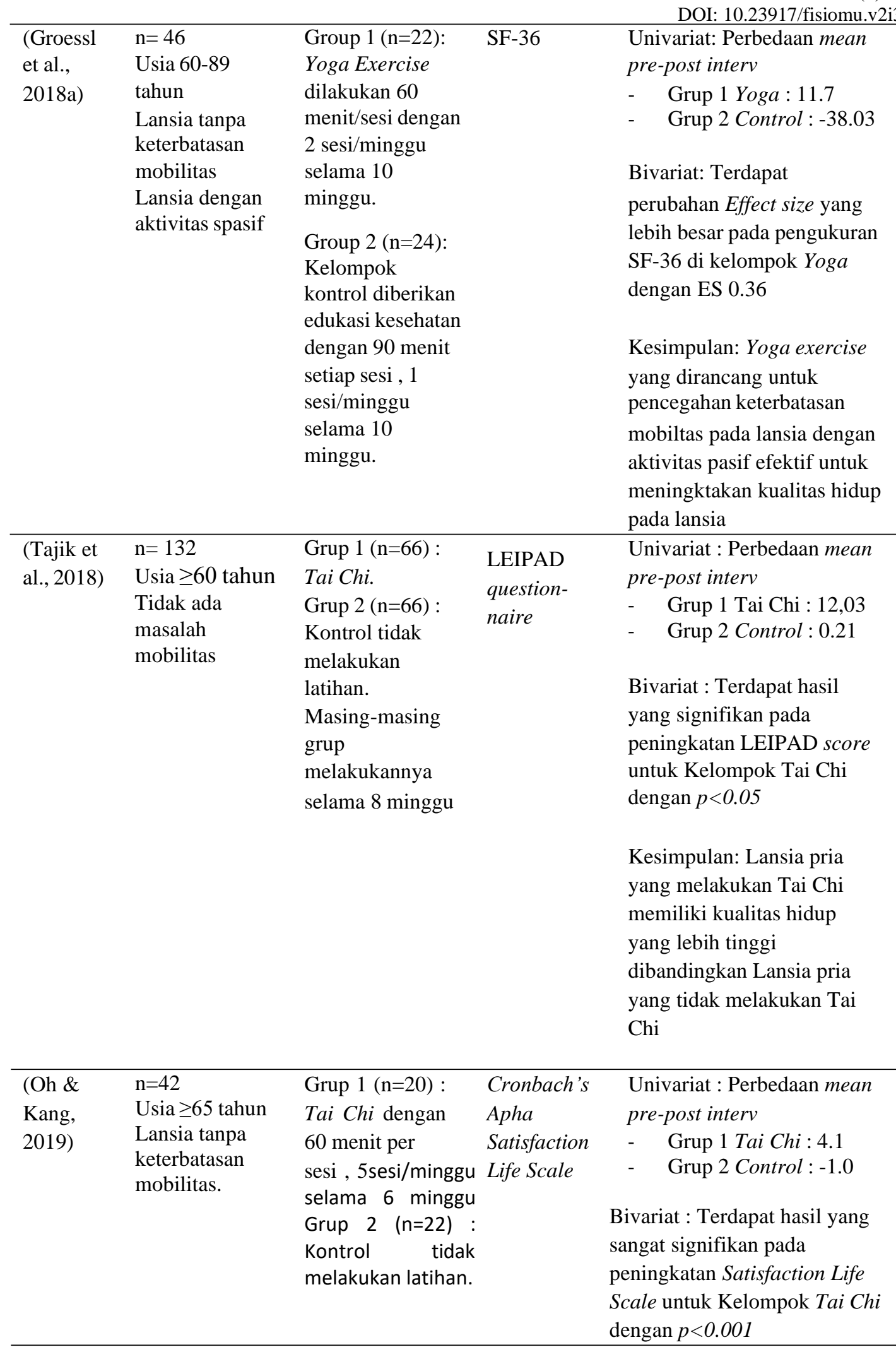


${ }^{1}$ N.A.W Aqila; A Qtrunnada; A.P Pasa; A.F Anggraeni, dan O.F Ningrum Fisiomu.2021 Vol 2(3): 162-175 DOI: $10.23917 /$ fisiomu.v2i3.15199

Kesimpulan: Tai Chi olahraga yang efektif dalam

meningkatkan kualitas hidup

lansia

\section{Pembahasan}

Penelitian ini $\begin{aligned} & \text { membahas tentang } \\ & \text { bagaimana Intervensi } \\ & \text { meningkatkan Kualitas }\end{aligned}$ Hidup Pada Lansia,
dengan mengkaji lima literature yang sudah
difilter sesuai dengan tahapan yang tertera.

Gabizon et al., (2016) menjelaskan bahwa terdapat 88 peserta yang dibagi kedalam dua kelompok, yaitu kelompok Pilates Exercise dan Kelompok Kontrol. Kriteria inklusi peserta dijurnal ini adalah usia lebih dari 65 tahun, lansia tanpa keterbatasan mobilitas. Alat ukur yang digunakan pada jurnal ini adalah SF-36. Kelompok Pilates melakukan pilates Exercise, sedangkan Kelompok Control tidak menerima intervensi apapun. Intervensi dilakukan selama 12 minggu dengan 3 sesi perminggu. Setelah melakukan intervensi selama 12 minggu kelompok Pilates Exercise menunjukkan bahwa status kesehatan mental lansia meningkat signifikan namun tidak memengaruhi status kesehatan keseluruhan lansia.

Tew et al., (2017) menjelaskan bahwa terdapat 52 peserta yang dibagi kedalam dua kelompok, yaitu kelompok Yoga Exercise dan kelompok Control berupa Health Education melalui booklet yang diberikan. Kriteria inklusi peserta dijurnal ini adalah usia lebih dari 60 tahun, lansia tanpa keterbatasan mobilitas. Alat ukur yang digunakan pada jurnal ini adalah EQ- 5D-5L. Kelompok Yoga melakukan Yoga Exercise, sedangkan Kelompok Control tidak menerima intervensi apapun. Intervensi dilakukan selama 12 minggu dengan 10 sesi perminggu. Setelah melakukan intervensi selama 12 minggu kelompok Yoga Exercise menunjukkan bahwa layak dan dapat diterima oleh lansia untuk perpanjangan rentang komorbiditas dan peningkatan kualitas hidup lansia.

Groessl et al., (2018) menjelaskan bahwa terdapat 49 peserta yang dibagi kedalam dua kelompok, yaitu kelompok Yoga Exercise dan kelompok Control berupa Health Education. Kriteria inklusi peserta dijurnal ini adalah pasien yang berusia $60 \quad-89$ tahun, Lansia tanpaketerbatasan mobilitas dan lansia dengan aktivitas spasif. Alat ukur yang digunakan pada jurnal ini adalah SF-36. Kelompok Yoga melakukan Yoga Exercise, sedangkan kelompok control melakukan Health Education. Intervensi Yoga dilakukan sebanyak 2 kali seminggu dengan 60 menit persesi dengan 2 sesi perminggu selama 10 minggu .Sedangkan untuk Kelompok Control melakukan intervensi selama 90 menit persesi 


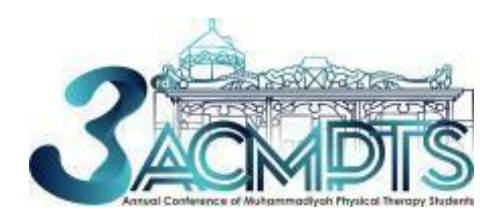

${ }^{1}$ N.A.W Aqila; A Qtrunnada; A.P Pasa; A.F Anggraeni, dan O.F Ningrum Fisiomu.2021 Vol 2(3): 162-175 DOI: 10.23917/fisiomu.v2i3.15201

dengan 1 sesi perminggu dilakukan selama 10 minggu. Setelah melakukan intervensi menunjukkan bahwa Yoga Exercise yang dilakukan untuk pencegahan keterbatasan mobiltas pada lansia dengan aktivitas pasif efektif untuk meningktakan kualitas hidup pada lansia.

Pada pengukuran penelitian ini didapatkan 5 alat ukur, diantaranya SF-36, EQ5D-5L, LEIPAD Quest, Cronbach's Apha, dan Satisfaction Life Scale. SF-36 (Short Form-36) digunakan untuk mengevaluasi status kesehatan kualitas hidup, yang terdapat pada jurnal Groessl et al., (2018) dan Gabizon et al., (2016). EQ-5D5L (European Quality of Life-5 Dimensions) digunakan untuk mengevaluasi status kesehatan kualitas hidup, yang terdapat pada Tew et al., (2017). LEIPAD Quest, kuesioner penilaian subjekif untuk menilai kualitas hidup lansia yang terdapat pada Tajik et al., (2018). Cronbach's Apha, digunakan untuk mengevaluasi status kesehatan kualitas hidup, yang terdapat pada Oh and Kang, (2019).

Dosis pada penelitian ini didapatkan durasi Latihan sebanyak $60 \mathrm{menit} / \mathrm{sesi}$ yang digunakan pada jurnal penelitian Tajik et al., (2018), Oh and Kang, (2019), Groessl et al., (2018), Gabizon et al., (2016), dan Tew et al., (2017). Frekuensi Latihan yang digunakan pada penelitian ini yaitu, 1 sesi perminggu yang terdapat jurnal dan Tew et al., (2017), 2 sesi perminggu terdapat pada jurnal Groessl et al.,
(2018), 3 sesi perminggu terdapat jurnal Gabizon et al., (2016), 5 sesi perminggu terdapat pada jurnal Oh and Kang, (2019), dan Tajik et al., (2018) tidak menyantumkan untuk penjelasan sesi pada jurnal tersebut.

Lamanya intervensi yang diberikan pada penelitian ini yakni, dilakukan intervensi selama 6 minggu terdapat pada jurnal Oh and Kang, (2019), intervensi diberikan selama 8 minggu terdapat pada jurnal Tajik et al., (2018), internsi yang diberikan selama 10 minggu terdapat pada jurnal Groessl et al., (2018), serta intervensi dapat diberikan selama 12 minggu yang terdapat pada jurnal Gabizon et al., (2016), dan Tew et al., (2017). Pembahasan diatas dapat diketahui bahwa intervensi yang diberikan lebih efektif jika diberikan selama 60 menit dengan frekuensi 5 sesi perminggu selama 6 minggu sehingga dapat meningkatkan Kualitas Hidup Pada Lansia.

Bentuk-bentuk latihan Intervensi Mind Body menggunakan gerakan dalam hubungannya dengan meditatif. Komponen dasar yang mencangkup pernapasan aktif dan pasif yang ditandai dengan berbagai tindakan seperti peregangan dan relaksasi otot rangka, tubuh terkoordinasi, tinggi tingkat konsentrasi, gerakan pernapasan teratur dan teknik pernapasan. Beberapa bentuk dari intervensi Mind -Body yaitu Yoga, Tai Chi, dan Pilates.

Latihan Yoga adalah terapi holistik yang berpotensi menghasilkan berbagai manfaat fisik, 
${ }^{1}$ N.A.W Aqila; A Qtrunnada; A.P Pasa; A.F Anggraeni, dan O.F Ningrum Fisiomu.2021 Vol 2(3): 162-175 DOI: $10.23917 /$ fisiomu.v2i3.15201

mental, dan social serta merupakan pendekatan alternatif untuk meningkatkan hasil kebugaran dan kesehatan pada lansia. Empat prinsip dasar yang mendasari ajaran dan praktik sistem penyembuhan yoga. Prinsip pertama adalah tubuh manusia adalah entitas holistik yang terdiri dari berbagai dimensi yang saling terkait yang tidak dapat dipisahkan satu sama lain dan kesehatan atau penyakit dari satu dimensi mempengaruhi dimensi lainnya. Prinsip kedua adalah kebutuhan yang harus disesuaikan dengan individu. Prinsip ketiga yoga memberdayakan diri sendiri. Prinsip keempat kualitas dan keadaan pikiran individu sangat penting untuk penyembuhan. Yoga yang dapat dilakukan oleh lansia yaitu, kombinasi postur, latihan pernapasan (Pranayama), teknik relaksasi, dan meditasi (Gerbarg, Wallace dan Brown, 2011)

Latihan Yoga yang digunakan pada Groessl et al., (2018) yaitu dengan membaginya ke dalam beberapa fase. Fase yang pertama dilakukan yaitu latihan pernapasan kemudian melakukan pose yoga dengan kecepatan yang secara bertahap meningkat selama 15 menit. Yoga dilanjutkan ke fase berikutnya dengan fokus utama standing pose selama 10-15 menit, floor pose selama 15 menit, dan supine resting pose selama 10 menit. Cukup berbeda dengan Yoga yang diaplikasikan pada penelitian Tew et al., (2017). Tew et al., (2017) menggunakan konsep Yoga yang dimodifikasi untuk lansia sehingga terdesain lebih aman, dengan jenis BWY Yoga.

Pose Yoga sebagian besar diaplikasikan dengan duduk di kursi ataupun dengan pose berdiri. Yoga modifikasi ini tidak menggunakan pose-pose lantai seperti terlentang, setengah terlentang ataupun tengkurap.

Latihan Tai Chi adalah sebuah kegiatan atau seni yang bertujuan untuk meningkatkan kesehatan fisik, keseimbangan jiwa, dan mental serta gabungan dari suatu kombinasi meditasi, yang berfokus pada pernafasan, dan gerakan fisik dengan irama tertentu yang menggerakkan 3 bagian tubuh dalam satu waktu secara bersamaan (Sutanto, 2013).

Tajik et al., (2018) menggunakan 10 gerakan Tai Chi dengan fokus latihan minggu pertama untuk adaptasi gerakan dan mingguminggu selanjutnya berfokus untuk meningkatkna performa motorik dan keseimbangan pada performa individu lansia. Oh dan Kang (2019) menggunakan 24 gerakan Tai Chi yang berisi (1) Commencing Form, (2) The Wild Horse's Mane on Both Sides, (3) The White Crane, (4) Spreads its Wings, (5) Brush Knee and Step Forward, (6) Playing the Lute, (7) Reverse Reeling Forearm, (8) Left Grasp the Sparrow's Tail, (9) Right Grasp the Sparrow's Tail, (10) Single Whip, (11) Wave Hands Like Clouds, (12) Single Whip, (13) High Pat on Horse, (14) Right Heel Kick, (15) Strike to Ears with Both Fists, (16) Turn Body and Left Heel Kick, (17) Left Lower Body and Stand on July $31^{\text {th }}, 2021$ on zoom cloud meeting Muhammadiyah University of Surakarta, Central Java, Indonesia 
${ }^{1}$ N.A.W Aqila; A Qtrunnada; A.P Pasa; A.F Anggraeni, dan O.F Ningrum Fisiomu.2021 Vol 2(3): 162-175 DOI: $10.23917 /$ fisiomu.v2i3.15201

One Leg, (18) Right Lower Body and Bird Stand on One Leg, (19) Works at the Shuttle on Both Sides, (20) Needle at Sea Bottom, (21) Fan Through Back, Turn Body, Deflect, Parry, and Punch, (22) Apparent Close Up, (23) Cross Hands, (24) Closing Form. Pada pengaplikasiannya, Oh dan Kang (2019) membatasi latihan sampai RPE 11 -13.

Latihan Pilates adalah metode latihan yang populer, memperkuat dan meningkatkan kontrol otot perut, punggung, panggul, dan pinggul yang lebih dalam serta meningkatkan kelenturannya.

Gabizon et al., (2016) membagi pengaplikasian Pilates kedalam tiga level. Level pertama yaitu menggunakan latihan dengan posisi terlentang yang bertujuan untuk mengaktivasi core muscle tanpa meningkatkan keseimbangan postur. Naik ke level selanjutnya yaitu menggunakan latihan dengan posisi duduk diatas swiss ball yang bertujuan untuk meningkatkan keseimbangan dan kontrol postur. Level terakhir yaitu menggunakan gerakan dengan posisi duduk yang dikombinasikan dengan thera band bertujuann untuk meningkatkan keseimbangan , kontrol postur, serta kekuatan.

Intervensi Mind Body yang melibatkan gerakan meditasi dapat berfungsi sebagai peluang yang meningkatkan domain kesehatan psikologis seperti kualitas hidup, gejala depresi, Fear of Falling (FoF), dan kualitas tidur pada lansia.
Meskipun Tai Chi dan Yoga lebih sering diterapkan daripada Pilates. Selanjutnya, ukuran efek kualitas hidup dan gejala depresi bergantung pada frekuensi latihan.

Dengan cara ini, bukti dari intervensi tersebut tidak hanya mempengaruhi dua tingkat yakni fungsi kognitif dan fisik tetapi juga berbagai domain fungsi psikologis di antara lansia. Hasil penelitian ini masih memiliki beberapa keterbatasan diantaranya, dalam proses pencarian literature terdapat beberapa jurnal yang berbayar dan adanya keterbatasan dalam pencarian sumber literature yang ada.

\section{Kesimpulan dan Saran}

Berdasarkan hasil pembahasan di atas maka dapat disimpulkan bahwa jenis desain studi yang dilakukan peneliti yaitu penelitian deskriptif dengan desain studi literatur. Jenis Intervensi yang efektif diberikan yaitu intervensi Tai Chi dengan dosis latihan aerobik selama 60 menit, dengan frekuensi 5 sesi perminggu dalam 6 minggu efektif untuk meningkatkan kualitas hidup lansia.

Berdasarkan hasil dan simpulan penelitian studi literatur ini maka Intervensi Mind Body efektif untuk meningkatkan kualitas hidup dengan meningkakan komponen- komponen kualitas hidup seperti kesehatan fisik serta mental. Fisioteapis dan masyarakat dapat menggunakan Intervensi Mind Body sebagai 
${ }^{1}$ N.A.W Aqila; A Qtrunnada; A.P Pasa; A.F Anggraeni, dan O.F Ningrum Fisiomu.2021 Vol 2(3): 162-175 DOI: $10.23917 /$ fisiomu.v2i3.15201

latihan rutin lansia yang dapat diaplikasikan di rumah masing-masing ataupun secara langsung dengan pengawasan.

Keterbatasan pada penilitian ini yaitu sulitnya mengakses bbrapa literatur dikarenakan akses tidak terbuka dan berbayar.

Saran yang dapat diberikan kepada penelitian selanjutnya dapat mencari sumber literatur dengan sumber berbayar, akurat, dan lebih luas jangkauannya.

\section{Ucapan Terimakasih}

Pada penyusunan studi literatur yang sederhana ini, penulis mendapat bantuan dari berbagai pihak. Oleh karena itu penulis mengucapkan terima kasih kepada: Bapak Ganesa Puput Dinda Kurniawan, SST, M.Fis sebagai Pembimbing 1, Dosen Fisioterapi Poltekkes Kemenkes Jakarta III serta Tim Penyusun yang berperan aktif selama proses penyusunan. Ucapan terima kasih juga kami disampaikan kepada semua pihak yang tidak dapat disebutkan satu persatu.

\section{Daftar Pustaka}

Gabizon, H., Press, Y., Volkov, I., \& Melzer, I. (2016). The effects of Pilates training on balance control and self-reported health status in community-dwelling older adults: A randomized controlled trial. Journal of Aging and Physical Activity,24(3),376383. https://doi.org/10.1123/japa.20140298
Groessl, E. J., Maiya, M., Schmalzl, L., Wing, D., \& Jeste, D. V. (2018a). Yoga to prevent mobility limitations in older adults: Feasibility of a randomized controlled trial. BMC Geriatrics, 18(1),112. https://doi.org/10.1186/s12877018-0988-8

Oh, C., \& Kang, H. (2019). Effects of tai chi exercise on the body composition, self- efficacy and life satisfaction of older adults in Korean local community. International Journal of Gerontology, 13(2), 134 138.https://doi.org/10.6890/IJGE.201 906_13(2) .0007

Tajik, A., Rejeh, N., Heravi-Karimooi, M., Samday Kia, P., Tadrisi, S. D., Watts, T. E., Griffiths, P., \& Vaismoradi, M. (2018). The effect of Tai Chi on quality of life in male older people: A randomized controlled clinical trial. Complementary Therapies in Clinical Practice, 33,191-196. https://doi.org/10.1016/j.ctcp.2018.1 $\underline{0.009}$

Tew, G. A., Howsam, J., Hardy, M., \& Bissell, L. (2017). Adapted yoga to improve physical function and health-related quality of life in physically-inactive older adults: A randomised controlled pilot trial. BMC Geriatrics, 17(1), 1-11. https://doi.org/10.1186/s12877-017-05206

Weber, M., Schnorr, T., Morat, M., Morat, T., \& Donath, L. (2020). Effects of mindbody interventions involving meditative movements on quality of life, depressive symptoms, fear of falling and sleep quality in older adults: A systematic 
${ }^{1}$ N.A.W Aqila; A Qtrunnada; A.P Pasa; A.F Anggraeni, dan O.F Ningrum Fisiomu.2021 Vol 2(3): 162-175

review with meta-analysis. International Journal of Environmental Research and Public Health, 17(18), 1-22. https://doi.org/10.3390/ijerph17186556

WHO. (2021). Ageing. World Organization Health. https://www.who.int/healthtopics/ageing\#tab=tab_1

Yogisutanti, G., Ardayani, T., \& Simangunsong,D. S. U. (2019). PENGARUH SENAM TAI CHI TERHADAP FLEKSIBILITAS DAN KEKUATAN OTOT EKSTREMITAS PADA LANSIA DI GEREJA BANDUNG BARAT. Journal of

\section{Public Health Research and Community}

Health Development, 2(1), 60. 'https://doi.org/10.20473/jphrecode.v 2i1.16 253

Badan Pusat Statistik (2020) Statistik Penduduk Lanjut Usia

Gerbarg, P. L., Wallace, G. and Brown, R. P. (2011) 'Mass disasters and mindbody solutions: evidence and field insights.', International journal of yoga therapy, (21), pp. 97-107. doi: 10.17761/ijyt.21.1.gn36102834522n 07.

Schoene, D. et al. (2019) 'A systematic review on the influence of fear of falling onquality of life in older people: Is there a role for falls?', Clinical Interventions in Aging, 14, pp. 701-719. doi: 10.2147/CIA.S197857.
Statistik, B. P. (2020) 'Survei Sosial Ekonomi Nasional (Susenas) Modul Ketahanan Sosial, 2020'.

Yu, X. et al. (2021) 'The Impact of Tai Chi on Motor Function, Balance, and Quality of Life in Parkinson's Disease: A Systematic Review and Meta-Analysis', Evidence-based Complementary and Alternative Medicine, 2021(2). doi: 10.1155/2021/6637612. 